\title{
Novi razvojni pravac između digitalne i ekohumanistike
}

Coulter, Kimberly, Wilko Graf von Hardenberg i Finn Arne

Jørgensen, urednici. Ant Spider Bee: Chronicling Digital

Transformations in Environmental Humanities. Spider \& Cloud, Rachel Carson Center for Environment \& Society, 2021, 235

str.

Knjiga Ant Spider Bee: Chronicling Digital Transformations in Environmental Humanities istodobno obuhvaća dva nova, zanimljiva i drugačija područja humanistike - digitalnu[1] i ekološku/okolišnu[ ${ }^{[2]}$ humanistiku. Budući da su dva navedena polja veoma kompatibilna i popularna, očekivano je da će doći do premrežavanja i prožimanja u novu disciplinu nazvanu digitalna ekohumanistika. Taj se proces i događa kroz posljednjih nekoliko godina - projekti poput Digital Environmental Humanities na Sveučilištu McGill u Kanadi[3], The Digital Environmental Humanities na Sveučilištu Umeå u Švedskoj ${ }^{[4]}$, Environment and Society na Sveučilištu LMU u München( ${ }^{[5]}$ itd., zatim počeci sveučilišne nastave iz digitalne ekohumanistike na spomenutim sveučilištima. Upravo su potonja dva projekta (iz Švedske i Njemačke) iznjedrila blog Ant Spider Bee (Mrav pauk pčela) ${ }^{[6]}$, pokrenut 2011. pod uredničkom palicom trojca Kimberly Coulter, Wilko Graf von Hardenberg i Finn Arne Jørgensen. Duhovito nazvan prema usporedbi o mravima, paucima i pčelama Francisa Bacona ${ }^{7]}$, ovaj projekt obuhvaća srž digitalne ekohumanistike. U izborniku bloga, „mravi” donose vijesti za zajednice (organizacija, udruge i akademiju), dok „pauci” sadržavaju obavijesti i dokumente o autorskim radovima i projektima, a „pčele” promišljanja o praksama i alatima digitalne humanistike. 
Istoimeni urednički trojac pripremio je zbornik radova pod nazivom Ant Spider Bee. Chronicling digital transformations in environmental humanities o digitalnoj ekohumanistici potaknut svojim dugogodišnjim blogom. Zbornik ima Predgovor i pet cjelina (I. Evolucija, II. Angažman: novi glasovi, III. Posredovanje: novi oblici, IV. Preobrazbe: nove prirode, V. Eksperiment u prikupljanju i održavanju) pri čemu je posljednja napravljena u obliku kratke biografske informacije o urednicima i autorima uz osvrt na dosadašnja postignuća projekta. Zbornik sadrži 40 radova iz pera 27 autorica i autora koji su veoma raznoliki (akademsko osoblje na sveučilištima, uredništva na specijaliziranim portalima, blogeri, knjižničari, književnici, umjetnici, muzealci, popularizatori znanosti i umirovljenici) i rade u Francuskoj, Kanadi, Njemačkoj, Norveškoj, SAD-u i Švicarskoj. Tekstovi su blogerski - pisani su popularnim stilom, relativno su kratki i opremljeni mnoštvom ilustrativnog materijala i linkova. Knjiga je digitalno izdanje na 235 stranica te je besplatno dostupna na linku:

www.environmentandsociety.org/sites/default/files/key_docs/antspiderbee_ebook.pdf.

Središnje ideje provučene kroz knjigu mogle bi se sintetizirati u tri cjeline. Prva cjelina koja zaokružuje zbornik društvene su mreže i blogovi. Nekoliko radova analizira mogućnosti blogova i društvenih mreža (\#envhist na društvenim mrežama kao što su Linkedln, Facebook, Twitter, Google Plus; podcasti Networking the Digital Environmental Humanities, alat poput PressForwarda) kao alata za digitalnu ekohumanistiku. Društvene su mreže još uvijek veliki potencijal koji nije potpuno iskorišten za promociju ekohumanistike. Međutim, budući da su inicijalno napisani u popularnom stilu, unutar ovih tekstova izostaje detaljnija analiza uzroka slabije iskorištenosti društvenih mreža u ekohumanistici.

Druga je nit vizualizacija. Ova riječ obuhvaća niz modela, alata i pojmova koji omogućavaju vizualizaciju podataka, analize ili promociju pomoću vizualnih materijala uključujući povijesni GIS[8] Ovdje se izdvajaju virtualne izložbe Welcome to the Anthropocene: The Earth in Our Hands, The Wegener Diaries: Scientific Expeditions into the Eternal Ice, Ludwig Leichhardt: A German Explorer's Letters Home from Australia i Reset Modernity! Navedene su izložbe napravljene na internetskim stranicama i obuhvaćaju slikovne, audio, vizualne i filmske priloge. Time je povećana dostupnost i omogućeno širenje znanja. Osim izložbe stvorene su i baze podataka Hurricane Digital Memory Bank, Eruptions, Earthquakes \& Emissions, Flyover Country i Polar Bear Trophy 
Imports, 1997-2008. Spomenute baze omogućuju pregledno vizualiziranje povijesnih informacije o pojedinim ekološkim problemima, npr. prirodne katastrofe ili lov na polarne medvjede. Ovi su podaci raznoliki i mogu poslužiti za daljnje analize. Uz sve navedeno na blogu se opisuju i druge prakse iz digitalne ekohumanistike kao što su vizualizacija Visualizing San Francisco Bay's forgotten past, interaktivne internetske platforme koje obuhvaćaju više aspekata digitalne humanistike, uključujući kvalitetne informacije, prezentacije, slobodni pristup (open access) i mogućnosti suradnje sa zainteresiranom publikom kao što su: Zooniverse, Arcadia, Environment and Society, Gaylord Nelson and the Making of the Modern Environmental Movement i Edge Effects te projekt Going Graphic. Posljednji je projekt zanimljiv jer autorica Jessica Van Horssen koristi grafički roman kao prezentacijski alat u kojem povezuje povijesna istraživanja te socioekonomske elemente današnjice grada i rudnika Asbestos u Kanadi. Osim popularizacije znanstvenog istraživanja i promocije ekohistorije, ovaj kreativni način diseminacije informacija približio je izazove i probleme korištenja azbesta kao i dugoročne posljedice. Veoma je kreativan i projekt Alicie Peaker izrađen na platformi Bl.ocks.org u kojemu ona vizualizira „više od ljudskog svijeta" u pojedinim književnim djelima (u radu je predstavila roman Gone to Earth, Mary Webb). Ovakav interaktivan pristup književnim djelima iz perspektive digitalne ekohumanistike više je nego potreban i izvrstan jer osim povezivanja baza podataka, vizualizacija i književnog djela, omogućuje mapiranje i analizu sadržaja pojedinih likova, pojmova ili ilustracija iz književnog djela.

Treća je poveznica popularna kultura pa tako pojedini radovi istražuju mogućnosti promocije preko intervjua (intervjuirane su Jenny Price o plažama Malibua i njenoj mobilnoj aplikaciji, Shih PeiChen o njenom projektu materijalnih socijalnih mreža prema klasičnim kineskim tekstovima), filmova, zvučnih projekata (projekt Call me! bilježi prirodne zvukove na ledenjaku Vernagtferner uslijed klimatskih promjena) i računalnih igara. U ovom su kontekstu zanimljiva dva rada autorice Alende Y. Chang o videoigrama. U prvom radu raspravlja o nasilju u videoigrama fokusirajući se na koncept sporog nasilja (slow violence) kao okolišne destrukcije, dok u drugom radu analizira FarmVille, Forbidden Island, Seal Slalom, Pirates of the Carob Bean, Flower of Journey i druge igre koje se nalaze na dostupnim platformama Animal Planeta, Greenpeacea i PETA-e. Osim toga, donosi i prijedloge za izvedbu nastave iz područja ekohumanistike pomoću videoigara. 
Zbornik Ant Spider Bee veoma je zahvalno i korisno štivo. S jedne strane omogućuje nam uvid u bezbrojne mogućnosti digitalne ekohumanistike koje su često besplatne, jednostavne i vrlo popularne, pa tako društvene mreže ili alati koje svakodnevno koristimo mogu biti motivacija i inspiracija za promociju našeg rada i povezivanje različitih aspekata humanistike kao što to omogućava digitalna ekohumanistika. S druge strane, otvara prostor za samostalno istraživanje korisnika u vidu vizualizacija, programskih jezika, kritičke analize sadržaja i diskursa. Jednako tako, zbornik je poticajan kao primjer online izdavaštva, besplatne i javno dostupne knjige koja je proizašla iz dugogodišnjeg projekta, međunarodne suradnje i multidisciplinarnosti pristupa. Nadam se da će urednici nastaviti s blogom Ant spider bee, a istodobno želim da svi mi koji se (rubno) bavimo digitalnom i ekohumanistikom promislimo o daljnjim platformama, alatima, programima i društvenim mrežama kao virtualnim mjestima za diskusiju, promociju, prezentaciju i organizaciju različitih sadržaja, pa priželjkujem da se razviju ovakvi i slični projekti na području Balkana / jugoistočne Europe. Uvjeren sam da je digitalna ekohumanistika jedno od najpotentnijih polja, što ova zbirka radova i pokazuje, pa vjerujem da će doći i do lokalnih inačica i razvoja regionalne digitalne ekohumanistike. 
[1] Digitalna humanistika (digital humanities, eHumanties, iHumanities) multidisciplinarno je polje koje obuhvaća humanističke znanosti i digitalne tehnologije te proširuje mogućnosti humanističkih istraživanja na digitalne analize, projekte s velikom količinom podataka (big data), baze podataka, vizualizacije, vizualne efekte, društvene mreže, komunikacijske tehnologije, digitalno pohranjivanje i prakse.

[2] Ekohumanistika ili okolišna humanistika (environmental humanities, ecological humanities, eco humanities) interdisciplinarno je akademsko polje koje prožima pitanja Prirode, prirode, okoliša, pejzaža/krajolika, reljefa, životne sredine i Zemlje s metodologijom humanistike, a sastoji se od niza poddisciplina kao što su ekofilozofija, ekoontologija, ekocentrizam, ekoantropologija ili antropologija okoliša, ekohistorija ili povijest okoliša, pejzažna arheologija, bioarheologija, arheologija okoliša, ekokritika, ekofeminizam, zeleni kulturalni studiji, kulturna botanika, animalistički studiji itd.

[3] Projekt je pokrenut davne 2013. i bio je dostupan na stranici http://dig-eh.org.

[4] Sažetak projekta i ciljevi: https://www.umu.se/en/research/projects/the-digital-environmentalhumanities/.

[5] Internetska stranica projekta: https://www.environmentandsociety.org

[6] Blog je dostupan na: www.antspiderbee.net.

[7] Francis Bacon, Novum Organum (1620) c.f. Ant Spider Bee: Chronicling Digital Transformations in Environmental Humanities, 2021, 10.

[8] Povijesni GIS obuhvaća niz metoda i alata GIS-a (Geografskog Informacijskog Sustava) primjenjivih na povijesna istraživanja, a napose na povijesnu kartografiju i prostorne analize koristeći povijesne izvore.

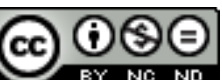

Creative Commons Attribution-NonCommercial-NoDerivatives 4.0 International License 